- RAM, REV. ADM. MACKENZIE, 15(6), Edição Especial • SÃO PAULO, SP • NOV./DEZ. 2014 • ISSN 1518-6776 (impresso) • ISSN 1678-6971 (on-line) • http://dx.doi.org/10.1590/1678-69712014/administracao.v15n6p201-219. Submissão: 19 jul. 2014. Aceitação: 30 out. 2014.

Sistema de avaliação: às cegas dupla (double blind review). UNIVERSIDADE PRESBITERIANA MACKENZIE.

Ana Silvia Rocha Ipiranga, Eloisio Moulin de Souza e Maria Luisa Mendes Teixeira (Ed. Convidados), p. 201-219.

\title{
PSYCHOLOGICAL WELL-BEING
}

\author{
AND PSYCHOLOGICAL DISTRESS FOR \\ PROFESSORS IN BRAZIL AND CANADA
}

\author{
ANA ALICE VILAS BOAS \\ Doutora em Administração pela Faculty of Education and Community Studies \\ da The University of Reading. \\ Professora associada III do Departamento de Administração e Economia \\ da Universidade Federal de Lavras (Ufla). \\ Campus Universitário, Caixa Postal 3.037, Lavras - MG - Brasil - CEP 37200-000 \\ E-mail:ana.alice@dae.ufla.br
}

ESTELLLE M. MORIN

Doutora em Psicologia pelo Departamento de Psicologia da Universidade de Montreal.

Professora titular do Departamento Service de l'Enseignement du Management

da Universidade de Montreal.

3000, Ch. Côte Ste-Catherine, Montreal, Quebec - Canada - CEP H3T 2A7

E-mail: estelle.morin@hec.ca

I The authors would like to acknowledge Coordenação de Aperfeiçoamento de Pessoal de Nível Superior (Capes) for the financial support for conducting this research.

Este artigo pode ser copiado, distribuído, exibido, transmitido ou adaptado desde que citados, de forma clara e explícita, o nome da revista, a edição, o ano e as páginas nas quais o artigo foi publicado originalmente, mas sem sugerir que a RAM endosse a reutilização do artigo. Esse termo de licenciamento deve ser explicitado para os casos de reutilização ou distribuição para terceiros. Não é permitido o uso para fins comerciais. 


\section{ABSTRACT}

Mental health, an important object of research in psychology as well as social psychology, can be determined by the relationship between psychological well-being and psychological distress. In this context, we search to understand: "How do compare mental health of professors working in public universities in an emerging country like Brazil with the one of professors working in a developed country like Canada?" and "What are the main differences in the indicators of mental health in work domain?". This paper assesses psychological well-being and psychological distress for professors working in these two countries and test for their differences. The sample consists of 354 Brazilian professors and 3I7 Canadian professors. Data were collected through an on-line questionnaire assessing the following mental health indicators: anxiety, depression, loss of control, general positive affect and emotional ties. We compared the components of psychological distress and psychological well-being to analyse their relations. Additionally, we compared these components with work-life balance indicator. Reliability analyses demonstrated that all tested components are consistent to evaluate mental health. There are small mean differences between Brazilian and Canadian professors in all five components of mental health, but these differences are not statistically significant. Mean differences for work-life balance, gender, age, and bias of conformity are statistically different, although the size effects are small. Linear regression analysis, step by step, controlled for life events, showed that general positive affect, anxiety and emotional ties predict 31.5\% of the scores of work-life balance. Additionally, we observed that Brazilian professors find more balance between professional and private life than do their Canadian colleagues. Promoting mental health is a challenge for public management sector, thus, public managers and governmental organizations can beneficiate from the studies of social psychology to improve work performance and the quality of the services offered to the society as well as to assist employees to improve their personal and professional life. 


\section{KEYWORDS}

Mental health. Bias of conformity. Life events. Human resources. Faculty.

\section{INTRODUCTION}

Mental health is considered a broad topic for studies because it is related to a set of activities aiming at making people capable of taking charge of their own health and improving their pattern of life. Mental health is rooted in the concept of "quality of working life" that represents the general state of well-being in the workplace that can be measured in terms of quality indicators, which can be assessed by various indicators such as high psychological well-being, low psychological distress, high organizational commitment and high work-life balance. (Ketchum \& Trist, I992). Thus, mental health is an important asset in the field of social psychology.

An academic career that was once viewed as safe, secure and high social standing environment to work, with opportunities of satisfying and autonomous work, is changed drastically nowadays. The growth of student numbers and the increase emphasis on research and higher quality learning that are tied up with constraints of economic pressure affect the level of job demand for professors and other faculty members. All these changes affect negatively the level on mental health in academic domain.

Gillespie, Walsh, Winefields, Dua and Stough (200I) affirm that university staff plays a vital role in the creation and development of knowledge and innovation, as well as education and training for the whole society. Thus, it is important that government and university managers find ways to protect their professors and other staff members form increasing levels of stress due to the increasing demands. As an example of this increasing demand in academic domain, we can point out the huge demand for publishing in high quality journals to support their careers and sustain the post-graduation programmes. In order to do so, professors need many times to assume technical activities in order to submit research projects, conduct researches and elaborate reports in order to obtain suitable material to publish.

On this matter, many studies focus the dilemma "publish or perish". To publish the professors need to work longer hours and dedicate themselves to their own researches and the researches of their master, doctorate and post-doctorate students. All these pressures lead to work-related stress, work-life imbalance, mental, physical and emotional strain, and different health problems. 
Some studies considering the indicators of quality of working life among professors explored the indicators of mental health, but they did not address the components of each indicator (Vilas Boas \& Morin, 2013a, 2013b, 2013c). In addition to this, according to our knowledge and researches, little is known about the mental health of faculty staff and professors. Thus, this paper assesses psychological well-being and psychological distress for professors in Brazil and Canada and test for their differences regarding the components of mental health in these two countries. In addition to this, we accessed work-life balance aiming to compare this indicator with mental health indicators.

\section{THEORETICAL BACKGROUND}

Programs that focus on the promotion of mental health at work are increasingly popular with employers. However, the majority of them consist to prevent psychological distress in the aim of stimulating the presence at work and the staff commitment in its daily activities. But, prevent psychological distress is not enough to promote mental health of employees.

For Gillespie et al. (200I, p. 54), "it is clearly important that universities manage and protect their staff from increasing levels of stress in order to preserve staff well-being, organizational performance and the intellectual health of the nation". However, this environment is always becoming more and more stressful what increase the problems of employees' health, well-being, satisfaction and motivation. It is relevant to states also that mental health can be affected by stressors like workload, work-related stress, low relationship quality or low sense of control under work, and working hours. By consequence, mental health can affect the balance between personal and professional life too.

The Ottawa Charter of the Organisation Mondiale de la Santé (I986) defines the promotion of mental health as a set of activities aimed at making people capable of taking charge of their own health and of improving it. Indeed, mental health is not simply the absence of mental disorders: "Mental health is a state of well-being in which every person realizes his potential, deals with normal difficulties of life, works with success of productive manner and can bring his contribution to the community" (Organisation Mondiale de la Santé, 2007, p. I).

\subsection{PSYCHOLOGICAL WELL-BEING AND PSYCHOLOGICAL DISTRESS}

The sense of dignity and self-achievement, presented by Ketchum and Trist (I992), can be associated with the concept of psychological well-being. In fact, 
the main components of psychological well-being are feeling of self-achievement, self-esteem and sense of balance. Moreover, Massé et al. (I998) demonstrated that psychological well-being and psychological distress are different, but complementary states of mental health.

Veit and Ware (1983) pointed out that mental health has two facets: psychological distress and psychological well-being. Anger or irritability, anxiety and exhaustion are typical states of psychological distress, as well as the tendency to devalue and an inclination to isolate, stay away, not engaging in activities with others. Experience these symptoms for two weeks may be a sign of distress. However, when the individual does not feel these symptoms it does not mean that the person is really fine. On the other hand, psychological well-being is often associated with happiness: a sense of balance and vitality accompanied by a feeling of self-worth are the most important characteristics. In these states we may add a sense of mastery and self-efficacy, a search for new relationships and the need of engaging in projects with others.

According to Massé et al. (1998), it is possible to prevent psychological distress without stimulating the psychological well-being. This is an important distinction to make, especially as more and more employers highlight their programs called "promotion of mental health".

In this domain, Massé et al. (1998) carried out a research in order to identify whether psychological distress and subjective well-being are the opposite poles of the same axis of mental health or independent constructs that should be measured on two independent axes. They produced two scales: a psychological distress manifestation scale (PDMS) based on 23 items and four factors (anxiety/ depression, irritability, self-depreciation, and social disengagement), and a psychological well-being manifestation scale (PWBMS) with 25 items and six factors (self-esteem, social involvement, mental balance, control of self and events, sociability, and happiness). Structural equation modeling analyses confirm that these ten factors can be viewed as components of two correlated dimensions (distress and well-being) of a two-dimensional latent construct, which reflects a higher-order concept of mental health. They conclude that assessment of mental health in general populations should use concomitant measures of psychological distress and psychological well-being (Massé et al., I998).

According to Veit and Ware (I983), mental health can be assessed by evaluating the five different components: anxiety, depression, loss of control, general positive affect and emotional ties. The first three components measure the level of psychological distress and the last two components measure the level of psychological well-being. For this study, we considered study as guideline for our research. 


\subsection{WORK-LIFE BALANCE}

According to Schneewind and Kupsch (2006), the research about worklife balance was marked, since the beginning of I980, by the determination of the sources of imbalance essentially associated with the job organization or staff management. Grzywacz and Carlson (2007) noted that the direction of the researches in this area changed early I990s. It is increasingly considered that work-life balance results from both the exchange and the negotiation of expectations between the individual and the employer. For Chrétien and Létourneau (20IO), the impacts of work-family conflict on employees' mental health are significant.

For Kahn, Wolfe, Quinn, Snoek and Rosenthal (i964, p. 20), work-life conflict is seen as a form of inter-role conflict where "role pressures associated with membership in one organisation are in conflict with pressures stemming from membership in other groups". Lewis (2003) postulates that for many workers, the boundaries between "work" and "non-work" have become increasingly overshadowed. It is probably because time and energy for personal life and leisure are being constantly spent in work demands.

In a stress survey in UK and Australian universities, Catano et al. (2010, p. 232) identified that "less secure employment status and work-life imbalance strongly predicted job dissatisfaction. Work-life imbalance strongly predicted increased psychological distress". In addition to this, they observed that "gender was the most consistent demographic predictor of work and health outcomes. Work-life conflict was the most consistent stress measure predicting work and health outcomes" (Catano et al., 20I0, p. 232).

Based on what was presented about the components of mental health, this paper analyze how Brazilian and Canadian professors evaluate psychological well-being and psychological distress, and what are the main differences between Brazilian and Canadian's point of view. Since it is the first study on this topic, to our knowledge, it is difficult to make hypotheses at this time. For this reason, the study presented here is considered exploratory.

\section{METHODOLOGY}

In order to determine whether there were differences between psychological well-being and psychological distress as perceived by Brazilian and Canadian professors, we invited professors from three federal universities in Minas Gerais - Brazil, and three provincial universities in Quebec - Canada, to answer an electronic questionnaire. The questionnaire was sent to: 
- 625 professors of the Federal University of A (UFA);

- 378 professors of the Federal University of B (UFB);

- 995 professors of the Federal University of C (UFC);

- $\quad$ I058 professors of the University du Quebec à A (UQA);

- $\quad$ 4I4 professors of the University du Quebec à $\mathrm{B}$ (UQB); and

- 207 professors of the University du Quebec à C (UQC).

The questionnaires were sent through Survey Monkey in the first semester of 20I3. In all, 67I professors completed the questionnaire, I30 UFA $(20.4 \%$ response rate), 75 UFB (I9.8\% response rate), I49 UFC (I4.9\% response rate), I96 of UQA (I8.4\% response rate), 73 UQB (I7.4\% response rate) and 48 UQC (23.2\% response rate). The returning rate of the questionnaires were low in each university, for this reason, it is hard to perform separate analysis by university, or even by department. But, regarding the total of questionnaires in each country, we have enough data to make the comparative analyses.

Among them, 3I2 were women and 359 were men. There is a significant difference between the distributions of gender in Brazil compared with Canada. In Brazil, there were 133 women and 22I men while in Canada, there were I79 women and 138 men. So, the sample in Brazil has a gender bias in favor of men.

The professors who volunteered to answer the survey were in average 45.03 years old (SD I0.427). There is a significant difference in the age of the respondents between Brazilians and Canadians $(t=-6.5 \mathrm{I2}, \mathrm{df}=669, \mathrm{p}<000)$. In fact, Brazilians $(\mathrm{N}=354)$ average age is 42.63 years ( $\mathrm{SD} 9.967)$ and Canadians $(\mathrm{N}=3 \mathrm{I} 7$ ) average age is 47.72 years (SD I0.286). In other words, Brazilian professors who answered the survey were younger than Canadian professors. This does not necessarily mean though that the Brazilian professors are in general younger that the Canadians, since we do not have the demographic data for the whole population of professors in both countries.

In this sample, $17.4 \%$ of professors have master degree; $70.8 \%$, doctorate degree; and Iı.8\%, post-doctoral degree. As for their civil status, $15.4 \%$ were single, $77.2 \%$ were married or live with a partner, $6.7 \%$ were either separated or divorced and $0.6 \%$ was widowed. Among the respondents of both countries, $65.3 \%$ have children and the majority of them has I child (20\%), 2 children (30.8\%) and 3 children (гі.6\%).

The questionnaire was designed to assess the mental health for university professors. More specifically, it includes scales that measure psychological well-being and psychological distress (Veit \& Ware, I983). The scale of Carlson, Grzywacz and Zivnuska (2009) was applied to assess work-life balance.

Since this survey aims at assessing sensitive indicators such as the professors' mental health and other personal issues, the analysis were controlled by 
events that have marked their histories. Thus, they were asked to answer by "yes" or "no" or "not applicable" if events such as the loss of a loved one, illness and job loss had occurred on their lives. The scale of Dohrenwend (I973) was used to measure the significant life events.

Similarly, it is important to control for the bias of conformity or social desirability that can influence the way the professors answer the questions. Indeed, when we ask people to express their opinions, some are more likely than others to conform to an opinion they believe are expressed by the majority of the respondents. The scale of Loo and Loewen (2004) was chosen; it has II statements that could be true or false. For example: "It already happened to me of feeling outraged against people in authority even though I knew they were right".

Demographic data were also asked in order to describe the sample and to better understand the results, including: gender, civil status, age, and university degree.

For each scale of the questionnaire, the principal component analysis with orthogonal rotation of factors was performed in order to reduce the observed variables to a minimum number of dimensions (or components) describing the maximum proportion of variance for each variables. The factorial structure of the scales was then tested using a principal axis analysis with orthogonal rotation. Once a clear factorial structure was found, we analyzed the internal consistency for each factor in order to assess their reliability, using Cronbach's alpha. This statistics can effectively determine the percentage of variance of error in the measurement of a factor, the acceptable level is at least 0.70 . From these analyzes, the variables were finally constructed and ready to be used for further analyses.

Before testing the differences between the two groups of professors, we examined the consistency of the indicators of mental health and work-life balance. For this purpose, correlation analyses were performed using the Pearson coefficient. We also performed linear regression analyses in order to explore the relations between the mental health's indicators (psychological well-being and psychological distress) and the work attitude's indicators (work-life balance).

Mean differences between the two groups were finally examined using the T-test procedure and size effects were calculated when significant mean differences were identified.

\section{MAIN RESULTS}

In this section, we present the main results of this comparative research. First, we discuss the relationship among mental health and work-life balance 
indicators for professors working in Federal Universities of Brazil and professors working in Quebec Universities, in Canada. Then, we compare the two samples to identify the main differences between Brazilian and Canadian professors' perceptions about these subject.

\section{THE RELATIONSHIP AMONG MENTAL HEALTH'S INDICATORS}

As it was previously defined, "Mental health is a state of well-being in which every person realizes his potential, deals with normal difficulties of life, works with success of productive manner and can bring his contribution to the community" (Organisation Mondiale de la Santé, 2007, p. I). If the components of mental health are consistent, the indicators we assessed will be strongly correlated and in a consistent direction. Furthermore, the balance between work and private life, are related to the balance between the time and the activities regarding the individual, his job and his family. Thus, this indicator should be also directly related to mental health.

In other words, professors who perceived a high quality of working life in their universities should obtain high scores for psychological well-being and high score for work-life balance. They should also get low scores for psychological distress. Also, the intercorrelations of these indicators should be significant and in a consistent direction, for example, psychological well-being and work-life balance should be positively correlated and the Pearson coefficient should be significant.

Table I presents the means, standard deviations, Pearson's correlation coefficients, number of items for each indicator and the index of internal consistency determined by Cronbach's alpha. As shown by the results presented in this table, the correlation coefficients are all significant and in the expected direction, showing the consistency of information that these measures present. The chosen components and indicators provided reliable information (because the internal consistency indices are greater than 0.70 ) and consistent information (because Pearson coefficients are significant and in the expected direction). The results for each of these indicators will be briefly described ahead.

\subsection{THE MAIN CONSTRUCTS}

There is a strong correlation - positive - between the depression and anxiety (0.7IO, $\mathrm{p}<0.000$ ). The size of the Pearson correlation coefficient means that the two components assess different aspect of the mental health, but they give consistent or coherent information about the latent variable they are supposed to represent, that is to say the mental health (Table I). Similarly, there is a strong 
correlation - positive - between the loss of control and depression (0.739, p < 0.000 ), but the size of the Pearson coefficient is not high enough to identify one with the other component. Similarly, there is a strong correlation - positive between loss of control and anxiety $(0.655, \mathrm{p}<0.000)$, indicating that components of psychological distress are consistent and in the desired direction to explain the scores of mental health.

There is a strong correlation - negative - between general positive affect and anxiety $(-0.700, \mathrm{p}<0.000)$, but not high enough to confuse the two components. There is also a strong correlation - negative - between emotional ties and depression $(-0.609, \mathrm{p}<0.000)$. In addition, there is a moderate correlation - negative - between emotional ties and loss of control $(-0.526, p<0.000)$ clearly indicating that they are two different indicators that can determine the relationships between psychological well-being and psychological distress.

There is a moderate correlation - positive - between work-life balance and emotional ties $(0.558, \mathrm{p}<0.000)$. There is also a moderate correlation - positive - between work-life balance and general positive affect $(0.548, \mathrm{p}<0.000)$, clearly indicating that they are consistent indicators to access work-life balance and psychological well-being. On the other hand, there is a moderate correlation negative - between work-life balance and anxiety $(-0.48 \mathrm{I}, \mathrm{p}<0.000)$. There is a moderate correlation - negative - between work-life balance and depression $(-0.407, p<0.000)$, indicating clearly that there are two possible ways to understand the relationship between the indicators of psychological distress and work-life balance.

In addition, there is a weak correlation - negative - rather significant, between bias of conformity and loss of control (-0.104, p < 0.000), indicating clearly that when social desirability increases, loss of control decreases. There is also a moderate correlation - positive - between life events and anxiety $(0.309, \mathrm{p}<$ 0.000 ), and a moderate correlation - negative - between life events and loss of control $(-0.302, \mathrm{p}<0.000)$, indicating clearly that when life events increases, anxiety also increases, however loss of control decreases. There is also a weak correlation - negative - between life events and the indicator of work-life balance $(-0.23 \mathrm{I}, \mathrm{p}<0.000)$, indicating clearly that when life events increases, work-life balance decreases.

There are also correlations - negatives - rather weak but, significant, between gender and the components of psychological distress. On the other hand, there are weak correlations - positives - between gender and the components of psychological well-being and the indicator of work-life balance. Apart from that, Age was significantly correlated only with anxiety (-I04, p < 0.000), bias of conformity $(0,255, \mathrm{p}<0.000)$, and general positive affect (0.IIO, $\mathrm{p}<0.000)$. 


\section{TABLE I}

MEANS, STANDARD DEVIATION, PEARSON CORRELATIONS AMONG COMPONENTS AND INDICATORS, SCORES OF INTERNAL CONSISTENCE AND NUMBER OF ITEMS (N = 67I)

\begin{tabular}{|c|c|c|c|c|c|c|c|c|c|c|c|c|c|}
\hline & MEANS & SD & & ANX & DEP & LOSS & GEN & EMO & WLB & CON & LIF & GEN & AGE \\
\hline \multirow{2}{*}{ ANXIETY } & 23.69 & 0.39 & (Alpha) & $(, 934)$ & & & & & & & & & \\
\hline & & & (nb items) & (8) & & & & & & & & & \\
\hline \multirow{2}{*}{ DEPRESSION } & 20.63 & 0.42 & r & ,710 & $(.923)$ & & & & & & & & \\
\hline & & & Sig. (bil) &, 000 & (3) & & & & & & & & \\
\hline \multirow{2}{*}{ LOSSCONTROL } & 14.48 & 0.25 & $r$ & ,655 & 739 & $(.876)$ & & & & & & & \\
\hline & & & Sig. (bil) &, 000 & ,000 & (6) & & & & & & & \\
\hline \multirow{2}{*}{ GENPOSAFFECT } & 40.27 & 0.38 & r &,- 700 &,- 694 &,- 615 & $(.942)$ & & & & & & \\
\hline & & & Sig. (bil) &, 000 &, 000 &, 000 & (9) & & & & & & \\
\hline \multirow{2}{*}{ EMOTIONTIES } & 45.99 & 0.43 & $r$ &,- 506 &,- 609 &,- 526 & 674 & $(.610)$ & & & & & \\
\hline & & & Sig. (bil) &, 000 & ,000 &, 000 &, 000 & (3) & & & & & \\
\hline \multirow{2}{*}{ WLBALANCE } & 27.97 & 8.53 & r &,- 481 &,- 407 &,- 370 & ,548 & ,558 & $(.906)$ & & & & \\
\hline & & & Sig. (bil) &, 000 &, 000 &, 000 &, 000 &, 000 & (6) & & & & \\
\hline \multirow{2}{*}{ CONFORMITY } & 13.77 & 1.91 & r &, 066 & ,088 & 104 &,- 071 &,- 070 &,- 016 & (.) & & & \\
\hline & & & Sig. (bil) & ,087 &, 023 & ,007 &, 067 & ,072 & ,687 & (11) & & & \\
\hline \multirow{2}{*}{ LIFEEVENTS } & 2.85 & 0.67 & r & ,309 & ,260 &,- 302 &,- 303 &,- 260 &,- 231 & 117 & (.) & & \\
\hline & & & Sig. (bil) &, 000 & ,001 &, 000 &, 000 &, 000 &, 000 &, 002 & (18) & & \\
\hline \multirow{2}{*}{ GENDER } & - & - & $r$ &,- 237 &,- 127 &,- 180 & 149 & 104 & 159 & ,036 &,- 071 & (.) & \\
\hline & & & Sig. (bil) &, 000 &, 001 & ,000 &, 000 & ,007 &, 000 & ,345 & ,068 & (1) & \\
\hline \multirow{2}{*}{ AGE } & 45.03 & 10.43 & $r$ &,- 104 &, 004 &,- 024 &, 051 & ,020 & ,053 & 255 &,- 049 & 110 & $(.906)$ \\
\hline & & & Sig. (bil) & ,007 & 920 &, 535 & 187 & 600 & , 169 &, 000 & ,203 &, 004 & (1) \\
\hline
\end{tabular}

Legend: Anxiety (ANXIETY), depression (DEPRESSION), loss of control (LOSSCONTROL), general positive affect (GENPOSAFFECT), emotional ties (EMOTIONTIES), work-life balance (WLBALANCE), bias of conformity (CONFORMITY), life events (LIFEEVENTS), gender and age.

Source: Prepared by the authors.

In general, the Brazilian and Canadian professors feel they have a good mental health and good work-life balance. They are psychologically well and they did not face many significant life events and are they have a good balance between 
work and personal life activities. At first glance, it seems that public university is a high quality work environment.

This being observed, are there significant differences between Brazilian and Canadian professors? This was our major research question and it is discussed in the sequence.

\subsection{COMPARISON BETWEEN BRAZILIANS AND CANADIANS}

To find out, the average scores on mental health's components and some variables of individual differences were compared using t-test for independent samples. The results of 354 Brazilian professors have been compared with those of 3 I7 Canadian professors. Table 2 presents the descriptive statistics for the two groups and the t-test for each variable.

Since signification bilateral or $\mathrm{p}$ is smaller than $5 \%$ for all of these indicators, we reject the hypothesis null (Ho) that the two samples are equals, and we accept the hypothesis alternative ( $\mathrm{Ha}$ ) that the sample of Brazilian and Canadian professors are different for some variables. T-tests allowed us to observe that all the five components of mental health are statistically equal between Brazilian and Canadian university professors. However, T-tests allowed us to find mean differences in bias of conformity, gender and age. But, their effect sizes are small.

The effect size is used to determine the value of mean differences between the two groups. It is determined with the calculation of eta squared $\left(\eta^{2}\right)$, using the formula below. The effect size for bias of conformity is ०.0I (small), for gender is $0.0 \mathrm{I}$ (small), and for age is O.०I (small).

$$
\eta^{2}=\frac{t^{2}}{t^{2}+\left(N_{I}+N_{2}-2\right)}
$$

Considering the results obtained for these two groups, it is concluded that the assessment of work-life balance by Brazilian professors is better than the assessment of Canadian professors. Canadians tend to face more social desirability than Brazilians. In this sample in there is a gender bias in favor of Brazilian men. Additionally, we can observe that Canadian professors who took part in this sample are, in average, older than Brazilian professors.

Brazilians and Canadians seem to experience different level of work-life balance, although both sample presented similar levels of psychological well-being and psychological distress in their universities. According to the results, Canadian professors reported more bias of conformity (I4.0662) than do Brazilian professors (13.4972) and this difference is significant, even though the size of the effect is small. 


\section{TABLE 2}

MEAN DIFFERENCES BETWEEN 354 BRAZILIAN PROFESSORS AND 317 CANADIAN PROFESSORS

\begin{tabular}{|c|c|c|c|c|c|c|}
\hline INDICATORS & NATIONALITY & $\begin{array}{c}x \\
\text { MEANS }\end{array}$ & $\begin{array}{c}S \\
\text { STANDARD } \\
\text { DEVIATION }\end{array}$ & $t$ & $\begin{array}{c}\text { DDL } \\
\text { DEGREE OF } \\
\text { LIBERTY }\end{array}$ & SIG (BI) \\
\hline \multirow{2}{*}{ ANXIETY } & Brazilian & 23,4499 & 9,58704 & $-0,643$ & 669 & 0,520 \\
\hline & Canadian & 23,9511 & 10,60306 & & & \\
\hline \multirow{2}{*}{ DEPRESSION } & Brazilian & 20,1130 & 10,49243 & $-1,290$ & 669 & 0,197 \\
\hline & Canadian & 21,1987 & 11,29922 & & & \\
\hline \multirow{2}{*}{ LOSSCONTROL } & Brazilian & 14,4680 & 6,38383 & $-0,033$ & 669 & 0,973 \\
\hline & Canadian & 14,4848 & 6,67964 & & & \\
\hline \multirow{2}{*}{ GENPOSAFFECT } & Brazilian & 40,1255 & 10,07118 & $-0,393$ & 669 & 0,695 \\
\hline & Canadian & 40,4241 & 9,55667 & & & \\
\hline \multirow{2}{*}{ EMOTIONTIES } & Brazilian & 45,6309 & 11,08785 & $-0,888$ & 669 & 0,375 \\
\hline & Canadian & 46,3933 & 11,11231 & & & \\
\hline \multirow{2}{*}{ WLBALANCE } & Brazilian & 28,6158 & 7,81401 & 2,049 & 622,654 & 0,039 \\
\hline & Canadian & 27,2555 & 9,21960 & & & \\
\hline \multirow{2}{*}{ CONFORMITY } & Brazilian & 13,4972 & 1,79273 & $-3,880$ & 640,323 & 0,000 \\
\hline & Canadian & 14,0662 & 1,98540 & & & \\
\hline \multirow{2}{*}{ LIFEEVENTS } & Brazilian & 2,85 & 1,739 & 0,013 & 669 & 0,990 \\
\hline & Canadian & 2,85 & 1,711 & & & \\
\hline \multirow{2}{*}{ GENDER } & Brazilian & 1,62 &, 485 & 4,976 & 657,170 & 0,000 \\
\hline & Canadian & 1,44 & ,497 & & & \\
\hline \multirow{2}{*}{ AGE } & Brazilian & 42,63 & 9,967 & $-6,501$ & 655,773 & 0,000 \\
\hline & Canadian & 47,72 & 10,286 & & & \\
\hline
\end{tabular}

Source: Prepared by the authors. 
In other to explore this result, a linear regression analysis was performed, controlling for the number of life events that has affected the participants. The variables that were chosen for the analysis were the following: age, gender, anxiety, depression, loss of control, general positive affect and emotional ties. The linear regression analysis, step by step, reveals that the variables that best explain work-life balance scores were: general positive affect, anxiety and emotional ties. The regression model obtained is presented on Table 3. This model explains $3 \mathrm{I} .5 \%$ of the variance of the score of work-life balance. The other variables were excluded from the regression equation.

TABLE 3

LINEAR REGRESSION ANALYSIS, STEP BY STEP, TO PREDICT

THE SCORE OF WORK-LIFE BALANCE WITH THE FOLLOWING VARIABLES: GENDER, AGE, ANXIETY, DEPRESSION, LOSS OF CONTROL, GENERAL POSITIVE AFFECT AND EMOTIONAL TIES, CONTROLLED FOR LIFE EVENTS (N = 67I)

\begin{tabular}{|c|c|c|c|c|c|}
\hline $\begin{array}{l}\text { MODEL WITH } \\
\text { THE RETAINED } \\
\text { FACTORS }\end{array}$ & $\begin{array}{c}\text { B } \\
\text { COEFFICIENTS } \\
\text { NON-STANDARDIZED }\end{array}$ & $\begin{array}{c}\text { SEB } \\
\text { ERROR } \\
\text { STANDARD }\end{array}$ & $\begin{array}{c}\text { B } \\
\text { BETA }\end{array}$ & $R^{2}$ & $\begin{array}{c}S^{2} \\
\text { ERROR STANDARD } \\
\text { OF THE ESTIMATION }\end{array}$ \\
\hline (Constant) & 15,444 & 2,356 & & 0,315 & 12,32318 \\
\hline GENPOSAFFECT & 0,275 & 0,046 & 0,325 & & \\
\hline ANXIETY & $-0,139$ & 0,037 & $-0,170$ & & \\
\hline EMOTIONTIES & 0,106 & 0,033 & 0,143 & & \\
\hline
\end{tabular}

$\mathrm{p}<0.05$.

Source: Prepared by the authors.

These results mean that after controlling for the number of life events each professor had, his or her score for work-life balance is best predicted by general positive affect (positive, more work-life balance a person perceive, more general positive affect he will feel), by anxiety (negative, less work-life balance led a more anxiety), and by emotional ties (positive too). Thus, we may confirm that work-life balance is positively relate to psychological well-being and negatively related to psychological distress.

It has to be noted that the gender and age of the respondents were not retained in the equation, suggesting that the perception of work-life balance is not a question of gender perception neither the age of respondents, but best explained by individual differences and attitudes toward mental health aspects. 


\subsection{DISCUSSION}

The survey asked to Brazilian and Canadian professors to assess their mental health and work-life balance and compare their perceptions about these variables. In general, the two groups seem to appreciate their psychologically well state, they did not face many significant life events and they have a good balance between work and personal life activities. However, there are not significant mean differences between psychological well-being and psychological distress between the two samples; in fact there are small differences between the evaluation that was made by Brazilians and Canadians regarding work-life balance. Indeed, it seems that Brazilians find more work-private life balance than do Canadians. Thus, how can we explain this result and relate it with mental health indicators?

As postulated by Veit and Ware (I983), we must distinguish the components of psychological well-being and the components of psychological distress in order to better describe mental health. The results of this survey clearly showed that university professors make difference between the two constructs and their components are significantly consistent as shown by Pearson correlation analyses. The components of psychological well-being (positive) and psychological distress (negative) are in the desired directions to explain the scores of mental health. These results are consistent with the statements of Chrétien and Létourneau (20I0) whom affirm that the impacts of work-family conflict on employees' mental health are significant and should be considered in social psychology and organizational behavioral studies.

The scores of work-life balance are positively correlated to the scores of psychological well-being. On the other hand, the scores of work-life balance are negatively related to the scores of psychological distress indicating, clearly, that there are two possible ways to understand the relationship between the indicators of mental health in public universities.

In addition, we observed that when significant life events increase, work-life balance decreases. There is also negative correlation between gender and the components of psychological distress, but there are positive correlations between gender and the components of psychological well-being and the indicator of work-life balance.

In particular, we observed that Brazilians and Canadians seem to experience different level of work-life balance, although both sample presented similar levels of psychological well-being and psychological distress in their universities. Brazilian professors reported more work-life balance (28.6158) than do Canadian professors (27.2555). This difference is significant, even though the size of the effect is small.

Linear regression, step by step, controlled for the number of life events showed that the score of work-life balance is best predicted by general positive 
affect (positive), by anxiety (negative), and by emotional ties (positive too). Thus, we confirm that work-life balance is positively relate to psychological well-being and negatively related to psychological distress, as postulated by Massé et al. (I998) whom demonstrated that psychological well-being and psychological distress are different, but complementary states of mental health.

\section{CONCLUSION}

This survey was designed to assess psychological well-being and psychological distress for university professors working in public universities in an emerging country like Brazil, with those of professors working in a developed country like Canada. Additionally, it was also designed to measure work-life balance in order to compare mental health with this indicator. In this exploratory study, the results show that in general, professors feel they feel psychologically well and they perceive good balance between professional and private life.

T-tests allowed us to observe that all the five components of mental health are statistically equal between Brazilian and Canadian university professors. However, T-tests allowed us to find mean differences in bias of conformity, gender and age. But, their effect sizes are small. Linear regression showed that the score for work-life balance is best predicted by general positive affect, anxiety, and emotional ties. In summary, we may say that work-life balance is positively relate to psychological well-being and negatively related to psychological distress.

Promoting mental health is a challenge for public management sector, but that is worth to be mentioned, because everyone will reap the benefits. Thus, public managers and governmental organizations can beneficiate from the studies of social psychology to improve work performance and the quality of the services offered to the society as well as to assist employees to improve their personal and professional life.

\section{BEM-ESTAR E SOFRIMENTO PSICOLÓGICOS PARA PROFESSORES NO BRASIL E NO CANADÁ}

\section{RESUMO}

Saúde mental, um importante objeto de pesquisa em psicologia e psicologia social, pode ser determinada pela relação entre bem-estar psicológico e sofrimento psíquico. Nesse contexto, buscamos entender: "Como se compara a saúde mental de professores que trabalham em universidades públicas em um 
país emergente como o Brasil com a saúde mental de professores que trabalham em um país desenvolvido como o Canadá?" e "Quais são as principais diferenças nos indicadores de saúde mental no domínio do trabalho?”. Este trabalho avalia o bem-estar psicológico e sofrimento psicológico para os professores que trabalham nesses dois países e testa suas diferenças. A amostra é constituída por 354 professores brasileiros e 3 I7 professores canadenses. Os dados foram coletados por meio de um questionário on-line visando acessar os seguintes indicadores de saúde mental: ansiedade, depressão, perda de controle, afetividade geral positiva e laços emocionais. Os componentes de sofrimento psicológico e bem-estar psicológico foram comparados para analisar suas relações. Além disso, comparamos esses componentes com o indicador de equilíbrio vida-trabalho. As análises de confiabilidade demonstraram que todos os componentes testados são consistentes para avaliar a saúde mental. Há pequenas diferenças de médias entre professores brasileiros e canadenses em todos os cinco componentes da saúde mental, mas essas diferenças não são estatisticamente significativas. As diferenças de médias para equilíbrio vida-trabalho, sexo, idade e viés de conformidade são estatisticamente diferentes, embora o tamanho do efeito dessas diferenças seja pequeno. A análise de regressão linear, passo a passo, controlada pelos eventos marcantes, mostrou que a afetividade geral positiva, a ansiedade e os laços emocionais preveem 3I,5\% dos escores de equilíbrio vida-trabalho. Além disso, observou-se que os professores brasileiros encontram mais equilíbrio entre vida pessoal e profissional do que os seus colegas canadenses. Como promover a saúde mental é um desafio para a gestão pública, os gestores públicos e as organizações governamentais podem se beneficiar dos estudos da psicologia social para melhorar o desempenho no trabalho e a qualidade dos serviços oferecidos à sociedade, bem como ajudar os funcionários a melhorar sua vida pessoal e profissional.

\section{PALAVRAS-CHAVE}

Saúde mental. Viés da conformidade. Eventos marcantes. Recursos humanos. Faculdade.

\section{BIENESTAR PSICOLÓGICO Y LA ANGUSTIA PSICOLÓGICA DE LOS PROFESORES EN BRASIL Y CANADÁ}

\section{RESUMEN}

La salud mental, un objeto importante de la investigación en psicología y psicología social, puede ser determinada por la relación entre el bienestar psicológico y 
la angustia psicológica. En este contexto, buscamos entender: “¿Cómo se comparan la salud mental de los profesores que trabajan en las universidades públicas en un país emergente como Brasil con el de los profesores que trabajan en un país desarrollado como Canadá?” y “¿Cuáles son las principales diferencias en los indicadores de salud mental en el trabajo de dominio?. En este trabajo se evalúa el bienestar psicológico y la angustia psicológica de los profesores que trabajan en estos dos países y la prueba de sus diferencias. La muestra está compuesta por 354 profesores brasileños y 3I7 profesores canadienses. Los datos fueron recolectados a través de un cuestionario on-line, evaluando los siguientes indicadores de salud mental: ansiedad, depresión, pérdida de control, la afectividad general positiva y lazos emocionales. Se compararon los componentes de los trastornos psicológicos y bienestar psicológico para analizar sus relaciones. Además, se compararon estos componentes con el indicador de balance trabajo-vida. El análisis de confiabilidad demostró que todos los componentes probados son consistentes para evaluar la salud mental. Hay pequeñas diferencias de medias entre profesores brasileños y canadienses en los cinco componentes de la salud mental, pero estas diferencias no son estadísticamente significativas. La media de las diferencias para el trabajo-vida balance, sexo, edad, y sesgo de la conformidad son estadísticamente diferentes, aunque los efectos son pequeños. Análisis de regresión lineal, paso a paso, controlado por eventos de vida, mostró que la afectividad general positiva, ansiedad y lazos emocionales predicen el 31,5\% de las puntuaciones de conciliación de la vida. Además, se observó que los profesores brasileños encuentran un mayor equilibrio entre la vida profesional y privada que sus colegas canadienses. La promoción de la salud mental es un desafío para el sector de la gestión pública, por lo tanto, los gestores públicos y las organizaciones no gubernamentales se pueden beneficiar de los estudios de psicología social para mejorar el rendimiento laboral y la calidad de los servicios ofrecidos a la sociedad, así como para ayudar a los empleados a mejorar su personal y la vida profesional.

\section{PALABRAS CLAVE}

Salud mental. Sesgo de la conformidad. Eventos de vida. Recursos humanos. Facultad.

\section{REFERENCES}

Carlson, D. S., Grzywacz, J. G., \& Zivnuska, S. (2009). Is work-family balance more than conflict and enrichment? Human Relations, 62(I0), I459-I486.

Catano, V., Francis, L., Haines, T., Kirpalani, H., Shannon, H., Stringer, B., \& Lozanzki, L. (20Iо). Occupational stress in Canadian universities: a national survey. International Journal of Stress Management, 17(3), 232-258. 
Chrétien, L., \& Létourneau, I. (20I0). La conciliation travail-famille: au-delà des mesures à offrir, une culture à mettre en place. Gestion, 35(3), 53-6I.

Dohrenwend, B. S. (1973). Events as stressors: a methodological inquiry. Journal of Health and Social Behavior, 14(2), I67-I75.

Gillespie, N. A., Walsh, M., Winefields, A. H., Dua, J., \& Stough C. (200I). Occupational stress in universities: staff perceptions of the causes, consequences and moderators of stress. Work \& Stress, 15(I), 53-72.

Grzywacz, J. G., \& Carlson, D. S. (2007, November). Conceptualizing work-family balance: implications for practice and research. Advances in Developing Human Resources, 9(94), 455-47I.

Kahn, R. L., Wolfe, D., Quinn, R., Snoek, I., \& Rosenthal, R. (I964). Organisational stress: studies in role conflict and ambiguity. New York: Wiley.

Ketchum, L. D., \& Trist, E. (I992). All teams are not created equal: how employee empowerment really works. Newbury Park: Sage.

Lewis, S. (2003). The integration of paid work and the rest of life: is post-industrial work the new leisure? Leisure Studies, 22(4), 343-355.

Loo, R., \& Loewen, P. (2004). Confirmatory factor analysis of scores from full and short versions of the Marlowe-Crowne social desirability scale. Journal of Applied Social Psychology, 34(I), 2343-2352.

Massé, R., Poulin, C., Dassa, C., Lambert, J., Bélair, S., \& Battaglini, A. (I998). The structure of mental health: higher order confirmatory factor analyses of psychological distress and well-being measures. Social Indicators Research, 45, 475-504.

Organisation Mondiale de la Santé (I986). Charte d'Ottawa pour la promotion de la santé. Retrieved july 27, 2013, from http://www.edm.ch/fr/documents/ChartedOttawa.pdf.

Organisation Mondiale de la Santé (2007). La santé mentale. Retrieved May, 20I2, from http:// www.who.int/features/qa/62/fr/index.html and http://www.who.int/mediacentre/factsheets/ $\mathrm{fs} 22 \mathrm{O} / \mathrm{fr} /$.

Schneewind, K. A., \& Kupsch, M. (2006). Perspectives psychologiques de la recherche sur les liens entre vie familiale et vie professionnelle. La Revue Internationale de L'éducation Familiale, 1(19), 9-30. Veit, C. T., \& Ware, J. E. (1983). The structure of psychological distress and well-being in general populations. Journal of Consulting and Clinical Psychology, 51(5), 730-742.

Vilas Boas, A. A., \& Morin, E. M. (2013a, September). Quality of working life in public higher education institutions: the perception of Brazilian and Canadian professors. International Journal of Business and Social Science, 4(12), 67-77.

Vilas Boas, A. A., \& Morin, E. M. (2013b, setembro). Indicadores de qualidade de vida no trabalho para instituições públicas de ensino superior: uma comparação entre Brasil e Canadá. Anais do Encontro Nacional da Associação Nacional de Pós-Graduação e Pesquisa em Administração, Rio de Janeiro, RJ, Brasil, 37.

Vilas Boas, A. A., \& Morin, E. M. (2013C, mai). Le sens du travail et la qualité de vie au travail dans les établissements publics d'enseignement supérieur: une comparaison entre le Brésil et le Canada. Poursuites de la Colloque International Afirse: Recherche en éducation: Continuité, rupture ou limites? Montréal: UQAM. 